\title{
3
}

\section{What's being there got to do with it? Distance, presence and belonging}

\section{Negotiating insider status}

Prominent in the promotion of the Australian memoirs of living in France is the positioning of the author as a cultural insider:

In My French Life, Vicki shares an insider's view of life in Francefrom its landscapes, delicious food, and scents to its charming people. And she offers an intimate portrait of what it's like to adopt a new home on the other side of the globe. (Archer 2006, publisher's description)

Clearly, a major selling point of the memoirs is the ability of the writer to provide insights not available to mere tourists. ${ }^{1}$ Thus Jane Paech includes 'insider dining tips' in A Family in Paris (2011, 97), Janelle McCulloch offers a chapter entitled 'La Vie Parisienne: From Expat to Insider' (2008, 223), and the cover of John Baxter's We'll Always Have Paris (2005) promises 'A charming insider's guide'. Emphasising the validity of the glimpse of life in France they offer, the authors invariably discuss the extent to which they feel they have achieved some form of insider status in France through being there, and with it a sense of belonging.

1 See Stephen Greenblatt on the rhetorical power of the eyewitness account in conferring authority (1991, 129). 
How, then, do the Australian authors, many of whom spend limited time in France, come to feel they have earned the status of insiders, and indeed accomplish this so quickly? Close examination of the books yields interesting patterns in the ways in which belonging is asserted, and this chapter traces these patterns. In doing so, it provides the opportunity for some initial exploration of the stories of these authors as they negotiate and gauge their relationship with their new place of residence, and in many cases discover limits to their feelings of attachment and inclusion. The chapter, then, does not afford a detailed focus on any individual memoir, but maps the ways in which the authors position themselves in relation to France, interpreting their trajectories of belonging as part of a wider cultural—and indeed transcultural—phenomenon. To this end, the analysis draws on several theoretical approaches-from spatial conceptions of belonging, through ideas of choice and performance, to belonging as momentum and process rather than an achievable state of being - in order to make sense of the stories of belonging and unbelonging recounted in the memoirs of being in France.

Establishing belonging in a foreign place is commonly conceived of as a story of arriving as a stranger, settling into a routine, forming attachments and gradually putting down roots until one feels at home to a certain extent. Certainly some of these elements are conspicuous in the memoirs of Australians in France. While the authors rarely mention hotels, planes, suitcases or monuments, they often describe cafés, kitchens and daily walks. The emphasis is on dwelling rather than travel, even when the stay in France is measured only in weeks, rather than months or years. And just as common as evocations of their favourite bakery or bookshop in their chosen corner of France are reflections on the extent to which they feel a sense of belonging. The few who bypass the topic are clear exceptions in the corpus. ${ }^{2}$ As we shall see, however, the focus on the habits and practices of dwelling only goes so far in explaining the dynamics of belonging in the memoirs, for the strongest feelings of affinity are often those expressed prior to or soon after arrival in France, and by those who live part-time in France. Curiously, belonging tends to be undone rather than entrenched as time passes, and seems better achieved at a distance, rather than in proximity to the local French population.

2 Those who avoid reflections on belonging are chef Stephanie Alexander (Cooking \& Travelling in South-West France), for whom the relationship to France was largely negotiated during a sojourn far in the past as an au pair and English teacher, and photographer Carla Coulson who concludes Paris Tango with a statement of her rootlessness, describing herself as 'the girl with an always-packed suitcase' (280). 


\section{Anything but a tourist}

The antithesis of the insider is the tourist, and so the first essential step in asserting belonging is to avoid resembling one. The top tourist sites are studiously avoided by the authors, who are almost unanimous in their disdain for tourists. ${ }^{3}$ As Ellie Nielsen writes in Buying a Piece of Paris, 'I haven't just galloped in to gaze up at the Tour Eiffel or queue up for Sainte Chapelle or sigh into the Seine' $(2007,171)$. Indeed, only Barbara Biggs (and then only before she buys a Paris apartment on a whim) and Ann Rickard do not reject outright the label of the tourist. Even among self-declared tourists, however, there is a pecking order. As a non-Frenchspeaking tour leader for a group of Australians who take over a small village, Rickard recounts a comic two-week 'romp' in Provence. But even she is able to feel superior-more at home in France-in comparison with a busload of American tourists apparently less enlightened than her troop:

[T] he Americans holidaying in Europe are quite a challenge: their loudness, their ignorance of all things outside their own country, their reluctance to even attempt a foreign word, their demands for cheeseburgers and Coke [...] (Rickard 2008, 152-53)

An obvious way to distance oneself from the tourist is to avoid carrying a camera. Mary Moody writes: 'I don't carry a camera and so I can even pretend that I'm a local' (2001, 203; cf. Ambrose 2005, 132-33). But even Sally Hammond, who dutifully recounts each scenic photo taken by her husband, is at pains to show her scorn for tourists and their tastes $(2002,73-74,98,144,183,184,195,214)$ and her aversion to 'tourist gimcrackery' (164). This she presents as setting her apart from run-of-the-mill tourists.

The trick to dodging the tourist label is to present oneself as belonging to a place, to a community. The ideal of being an 'insider' is also expressed as being a 'local' (Corbett 2007, 36, 62; Moody 2001, 173), an 'honorary Parisian' (Corbett 2007, 247) or an 'honorary villager' (Lawrence 2004, 177), or indeed as having a 'French life' (Archer 2006; Webster 2012, xvii; Cutsforth 2013, 247; see Chapter 5), labels that all help to validate the version of French life that is presented.

3 Holland and Huggan point out the irony of the contribution of the travel writer to the tourist industry they claim to scorn $(1998, \mathrm{xi})$. 
Among the Australians, a favourite means of achieving this status is through frequenting bars and cafés:

Also helping me to make the transformation from blow-in to local was a trio of café-bars at the end of my street, whose mortgages I helped pay off with my faithful custom. (Corbett 2007, 36)

After six months of faithful patronage, we became grudgingly accepted as locals. [Le Connétable] became our bar of choice when all others had closed. (Corbett 2007, 84)

After about a month of regular visits to the bar, something momentous happened one morning that confirmed the elevation of my status beyond that of a mere tourist. (Lawrence 2004, 176)

Christian and Christiane [the proprietors] greet me like a member of their family. The local barflies smile in recognition and kiss me on both cheeks [...] (Moody 2005b, 103, cf. 2003, 81)

I love to linger in Parisian bistros, bars and cafés, soaking up the atmosphere and the chat. It makes you feel as though you really are a part, albeit a small one, of Parisian society. (McCulloch 2008, 148, cf. 233)

Time at the bar makes them feel like locals, even if, ironically, the quantities of alcohol they drink there mark them out as foreign, even underline their Australianness (see Chapter 9). Regular contact with shopkeepers is another useful approach:

I felt like I had been accepted as a local. I could walk the Rue de Levis and be plied with free honey, the serveuse in the boulangerie had started to make a point of giving me a baguette 'pas trop cuit' (not too crusty), just as she knew I liked it (Stafford 2010, 218).

In my neighbourhood, I had been accepted as a local to the extent the baker had stopped routinely giving me the most stale baguette in the shop. (Corbett 2007, 62)

as is buying real estate:

I start telling all my friends the fantastic news. I am going to buy a house. Become a local. Come back every year. (Moody 2001, 262) 
Sally Hammond's strategy is to adopt a French village:

The trick is to visit whenever possible and learn it inside out. Discover its idiosyncrasies, talk to the local shopkeepers, sniff out the finest places to eat and drink and picnic everywhere you canas we have with Azé—-to make it your own. $(2007,91)$

This similarly enables her to claim insider knowledge and a form of belonging. All these techniques involve establishing spatially anchored routines in France.

\section{Belonging as embodied practice}

Nigel Rapport underlines the importance in a world of travellers of 'a routine set of practices, [...] a repetition of habitual interactions' in establishing a sense of home $(1995,268)$, and the memoirs highlight the repetition of leisurely local routines. Whether in Paris or the provinces, engagement with place is foregrounded as the protagonists take that same little walk through the rue de Buci market near Saint-Germain-desPrés (McCulloch 2008, 10), frequent that same café in rue Montorgueil (Turnbull 2002, 121-24), and visit the flower markets in Saint-Rémyde-Provence on a weekly basis (Archer 2009, 10). ${ }^{4}$ They establish habits that signal them as inhabitants in their chosen place in France. Janelle McCulloch writes:

It is some time now since I arrived in Paris and I have settled into the city like an old soul, into a daily routine of writing stories [...] for several hours a day at one of my favourite cafés and then strolling the streets of Paris thereafter, finding solace among the beauty of the city's bewitching streets. I have started to feel the rhythms of the city and understand the different tempos of the Parisian day. $(2008,80)$

It is these kinds of practices that Michel de Certeau identifies as constituting everyday life. For de Certeau, walking in the city is an appropriation of space, a way of making it one's own, that produces a way of being, a style, a lifestyle: 'it is a process of appropriation of the topographical system on the part of the pedestrian' $(1984,97)$. The sediment of repeated practice similarly contributes to the formation of

4 Jean Duruz comments on the use of markets by travel writers as 'repositories' of belonging (2004, 428). 
Pierre Bourdieu's concept of habitus (1984). Habitus is incorporated, inscribed in and through the body to become a way of being, thinking and acting, a groove of behaviour where we feel at home, a certain style that defines one's place in both the social and spatial senses of the word. Both de Certeau and Bourdieu underline the productive nature of repeated practice. As de Certeau's French title L'Invention du quotidien (literally 'the invention of the everyday') indicates, these embodied routines are productive, capable of generating a social identity, a form of belonging. This creative aspect is similarly emphasised by Bourdieu, when he explains his choice of the term habitus:

The habitus, as the word implies, is that which one has acquired [...] But then why not say 'habit'? Habit is spontaneously regarded as repetitive, mechanical, automatic, reproductive rather than productive. I wanted to insist on the idea that the habitus is something powerfully generative. $(1993,87)$

Far from merely mechanical, the repetition is considered creative, a spatial practice constantly generating and mapping a social identity. For these habits and routines express judgements of taste, and are thus acts of social positioning. They may convey distinction or its antithesis; in either case, they contribute to establishing social class.

For those wishing to distinguish themselves from the experience of mass tourism represented by the Eiffel Tower, an alternative set of 'sacred sites' (Rojek and Urry 1997, 12) has evolved. The pâtisserie Ladurée is one such place of pilgrimage:

I'd pause here [Ladurée] on an almost weekly basis [...] I love to come to this irresistible patisserie when I want to be reminded of how beautiful Paris can be-and how even a simple macaroon can become art. (McCulloch 2008, 10)

It appears regularly in the Paris memoirs (Lawrence 2017, 176; Paech 2011, 285; Stafford 2010, 265; Turnbull 2002, 134), conferring distinction on the authors, and also making it available to their audience. ${ }^{5}$

5 Caroline Oliver points out the class function of this discourse for the traveller/author: 'Traditionally, migrants' disdain for tourists may be conceptualized as a matter of distinction [...]; the assertion of class status through style' $(2006,198)$; while Sallie Tisdale signals its role for the reader in 'Never Let the Locals See Your Map', noting that contemporary travel books serve to flatter middleclass readers 'who wish to separate from the rabble' of vulgar tourists $(1995,68)$. Cf. Holland and Huggan 1998, viii. 
Earning social distinction through European travel has a long history in Australia, particularly for women. As mentioned in Chapter 2, Ros Pesman found the wives and daughters of the colonial élite travelling to Europe to acquire 'badges that proclaimed status, refinement and culture' $(1996,24)$. The advent of mass tourism, however, has meant that travel to France is no longer sufficient to obtain prestige. In an era of mass travel, it is the fact of living in France, belonging there as opposed to merely travelling there, that gives cachet, hence the importance of establishing one's status as a resident, however temporary. So rather than tales of travel, we find ourselves reading accounts where the pleasures include familiarity with that little-known side street, intimate knowledge of that tucked-away market, and dishes, purchases and experiences that the tourist will likely never stumble upon. Ellie Nielsen's dream is of 'private Paris', an invitation-only version of the city not available to tourists: 'Any visitor could delight in public Paris. What I coveted was the élan, the exactitude, of private Paris' like that of her friend's aunt, whose Paris is 'the inner sanctum-not the Paris you could be privy to by chance' $(2007,82)$. Similarly, McCulloch is determined to go beyond the Lonely Planet guide $(2008,54)$ and 'find The Real Paris, [...] the Paris that only truly dedicated devotees of the city bother to look for, and in doing so, I surmise — or at least I hope with all my heart—-that I shall become just a tiny bit more Parisian' (57). And it is the first-hand connection with place that will lend authority to the narrative and confer the cultural identity she desires.

By avoiding tourist monuments and alluding to their favourite pastry shop, butcher and market vendor, through their choices of destination, routine and pastime, the authors of the memoirs acquire a veneer of French belonging that serves to distinguish them not only from tourists but from more 'ordinary' Australians. The assertion of belonging in France thus serves a class function, and not only for the author but also the reader, who is invited to emulate the traveller, often at a distance. To this end, a number of the memoirs function as manuals of belonging, by including tips and appendices ${ }^{6}$ to assist the armchair traveller to

6 See for example Archer's lists of addresses of restaurants and boutiques, and of films, music, books (2006, 220-28); Holdforth's reading list (2004, 222-26); Lawrence's bibliography (2017); Asher's self-help advice (2011); and Paech's framed sections offering tips (2011). See Chapter 5 on the use of these to coach the reader. 
practise a particular kind of 'Frenchness', whether at home or abroad, through lifestyle changes, café culture, culinary accomplishments, interior decorating and further reading.

\section{Gauging belonging}

In the memoirs, the level of belonging established through such routines and rituals is, to a very large extent, assessed in relation to other Anglophones. Although there are occasions when authors report feeling like a local in response to a smile from the concierge (Paech 2011, 243) or recognition by a shopkeeper, in general, 'being a local' is not a position negotiated directly with the French; rather it is a competition for distinction played out among travellers and would-be travellers, a contest with France as the unwitting prize and the reader as arbiter. That is to say, it requires a detour through an elsewhere. An extreme and overt example is Margaret Ambrose in How to be French. In a passage of apparently unintended irony, she derides the tactics used by fellow Australians who attempt to be French, tactics she herself uses on the very same page:

Aussie Bogan wasn't the only person who wore Paris as a badge of honour. Such is the mystique and mythology of the city that some women think that by claiming it as their own, somehow the glamour and beauty will become part of their own personality. [...] Another, less subtle way of aligning oneself with Paris is to not only announce yourself as Paris Woman, but to tell everyone else they are not. $(2005,42)$

During her short visit to Paris, she smugly stakes her claim in this way:

It made me feel more at home and less of a foreigner watching other foreigners sitting at the ridiculously overpriced restaurants along Rue de Rivoli. With their cameras and their high school French I could feel their anxiety and it pleased me to think I might not be quite at home but at least I am not like them. (132-33)

At the other extreme of residence in France, the pecking order of belonging is equally strong, but there is less need to distance oneself from the wide-eyed tourist; rather, length of stay separates the seasoned expats from more recent arrivals. The jockeying to belong, however, still plays out without reference to the opinion of the French: after his first decade or two in Paris (in a book that spans half a century of residence), Kershaw looks down on 'other foreigners established for only two or three years in the city, hobnobbing exclusively with their fellow countrymen' $(1993,65)$, a sentiment echoed by Corbett who, after six years in Paris, 
self-mockingly describes his development of 'a deep and abiding dislike of tourists and tendency to dismiss anyone who had spent less than five years in the city as a Johnny-come-lately Paris part-timer' (2007, 344).

But while playing this game lends weight to the insider's view of life in France, we can imagine that the French remain oblivious to-or perhaps bemused by - the competition to belong. Their judgement on the integration of the Australians can be deduced from chance encounters, replies and glances: the beggar who spontaneously addresses Ellie Nielsen in English $(2007,7)$; the stares in reaction to her 'bonjour' in the estate agent's office (5); 'the habit among Parisians of always replying in English whenever I spoke to them in French' (Corbett 2007, 62); 'when a shopkeeper or passer-by addresses me in English even before I've opened my mouth' (Turnbull 2002, 294, original emphasis). For tasteful daily routines are in themselves no guarantee of belonging. However at home the authors might feel, to the French they often simply remain foreigners. Despite her fluent French and five years in Provence running a successful business, with three properties and children at school there, Henrietta Taylor, in Lavender and Linen, receives a deflating reality check from a native of the region:

'Madame Taylor, no matter how long you live here, no matter how proficient your French is, you will never be anything but a tourist for the people around here. Likeable, admittedly, an extremely hard worker, granted; but it takes generations to become a real Provençal.' (2008, 173)

The perspective of the French on the Australians' belonging is, however, ultimately of secondary importance in the memoirs, for the insider status claimed by the authors is primarily for export use, bolstering what Ross Chambers terms 'narrative authority' $(1984,51)$-the authority of the narrator as the one who knows-for the benefit of the Anglophone reader, who is expected to ratify it from across the globe.

Nonetheless, interactions with local Francophones tend to undermine feelings of belonging in the memoirs. After several weeks of getting to know her partner's family, Nadine Williams in From France with Love confides: 'I can't even articulate how different I feel from the women here, so free from the constraints I see around them' $(2007,228)$. After her first dinner party, Sarah Turnbull confesses, 'Although everyone had been very pleasant, I'd felt totally out of place at the dinner. Fitting in and making friends might be harder than I expected' $(2002,51)$. And by the time 
she has spent eight years in France, and is married to a Frenchman, she understands that she is viewed by the French as permanently alien, giving the lie to her title Almost French:

I could stay here thirty years, even take out French nationality, but that won't change how people perceive me. My identity in my new homeland is defined by my country of origin. (295)

The fine distinctions between levels of belonging elaborated by some of the authors apparently amount to little from the perspective of the native French, for whom the claims to Frenchness are merely fanciful.

Here it is helpful to extend Judith Butler's theorisation of performative identity (1990) to include belonging, as Vikki Bell does in 'Performativity and Belonging'. Like identity, belonging can be understood as constituted by the repeated performance of particular routines, without ever being definitively achieved:

the performativity of belonging 'cites' the norms that constitute or make present the 'community' or group as such. The repetition, sometimes ritualistic repetition, of these normalised codes makes material the belongings they purport to simply describe. (Bell 1999, 3)

Belonging thus needs to be continually created, through the repetition of its performance.

The notion of performance suggests the benefits of practice, such that we could anticipate a more convincing performance of belonging as time passes in one's chosen destination. Curiously, however, in the Australian memoirs, length of stay does not correlate with belonging, and indeed the strongest expressions of belonging tend to occur early in the narrative, on or even before arrival in France, only to diminish thereafter. Rather than practice making perfect, there appears to be a failure in the performance in France at some level. It is as if the principal work of belonging was in fact carried out prior to travel, with the implicit expectation that it will be validated on arrival. Ambrose, for example, writes that in Melbourne, well before she sets foot in France, 'Just stepping through the doors of the Alliance Française language school made Freda and I feel French' $(2005,11)$, a feeling that contrasts with her bewilderment later on at the alien rules for occupying space in the Paris metro (49). To understand the ebb and flow of belonging in these memoirs, then, we need to look at what precedes the reiterated performance of embodied practices. 


\section{Elective belonging}

The neighbourhoods of Manchester are an unlikely model for understanding Australian feelings of belonging in Paris or Provence, but the work of Savage, Bagnall and Longhurst in Globalization and Belonging proves useful. Their analysis of interviews with both longstanding Mancunians and recent arrivals is revealing of contemporary dynamics of belonging, which are not necessarily the product of lengthy residence and integration in a local community. Extending Bourdieu's elaboration of habitus and field (field being the particular arena for human interaction, a socially stratified sphere of activity), Savage et al. develop the concept of 'elective belonging' to explain how a sense of belonging can be heightened through mobility:

People are comfortable when there is a correspondence between habitus and field, but otherwise people feel ill at ease and seek to move-socially and spatially-so that their discomfort is relieved. [...] Mobility is driven as people, with their relatively fixed habitus, both move between fields (places of work, leisure, residence, etc.), and move to places within fields where they feel more comfortable. $(2005,9)$

According to this logic, people feel driven to move when their sense of self is incongruent with the position they occupy in their usual place of residence, when there is discomfort in what should be the comfort zone. Thus they seek correspondence between these two elsewhere, 'seeing places as sites for performing identities' (29). ${ }^{7}$ For the authors of the Australian-in-France memoirs, France is seen as a site for performing a more stylish, refined identity. Feelings of dissonance between oneself and one's surroundings prompt the travel recounted in several cases. Janelle McCulloch, in La Vie Parisienne, emphasises the lack of fit between her sense of self and the Victorian country town where she grew up:

Country towns are agonising for young girls who read Vogue, [...] and dream of European streets and dark-eyed men in poetic black polonecks reading Proust with a French accent. [...] I couldn't wait to leave. I felt like the odd one out: the misfit, the dreamer, the proverbial square peg. $(2008,19)$

7 Cf. Pesman's discussion of projection among Australian women travellers: 'the women had travelled long before they embarked on their journeys, had named their places, taken possession' (1996, 159). 
The mismatch is echoed in John Baxter's description of his youth in We'll Always Have Paris:

In my jaded view, Australians swam like fish and thought like sheep. I wanted out.

My life entered a phase of dual existence. Sitting in the Koala Milk Bar drinking a milkshake, I could squint my eyes and transport myself in imagination to the Café Radio on Place Blanche in Montmartre. [...] Another day, while I might be pushing my bicycle along a cracked concrete pavement under the pungent pepper trees of Junee, my world circumscribed by a horizon shimmering in 40-degree heat, in fantasy I stood rapt in the early summer of 1925 under blue skies in a light breeze on Place du Trocadéro. $(2005,18)$

In moving to France, they elect to live in a place they see as mirroring their identity. Australia is weighed up against France and is found wanting. As Savage et al. put it:

This kind of elective belonging is critically dependent on people's relational sense of place, their ability to relate their area of residence against other possible areas, so that the meaning of place is critically judged in terms of its relational meanings. $(2005,29)$

Unlike the traditional understanding of belonging, which involves 'attachment to what is near to you', elective belonging 'evokes attachments to distant places' $(2005,103)$ :

Elective belonging exists in a tension between an instrumental and functional orientation to place on the one hand, and powerful, emotional and auratic yearnings on the other. Such emotional attachments, we emphasise, need not be conferred by a history of long residence, or by being born and bred in a particular area, but are related to people mapping their own biography through identifying places dear to them. $(2005,103-104)$

Savage et al. assert that those who feel the greatest sense of belonging are those who "attach their own biography to their "chosen" residential location, so that they tell stories that indicate how their arrival and subsequent settlement is appropriate to their sense of themselves' (29). This use of narrative to implement belonging is evident in the memoirs, especially in the expressions of a sense of homecoming on arrival in France: Jane Webster in At My French Table comments that 'The reverential way 
in which the French treated food [...] made me feel as if I'd come home' $(2008,2)$; Janelle McCulloch thinks back to her first visit to Paris and writes, 'I remember thinking, [...] that I felt strangely at home. For some reason, I finally felt, as the French say, happy in my own skin' $(2008,26)$; and Stephen Downes in Paris on a Plate notes that on his first visit to France, 'Instantly, weirdly and without reason, I felt strangely at home' $(2006,13)$.

From this perspective we see that, in the memoirs, rather than spatial practices establishing belonging, the habitual walks and visits to cafés are attempts to authenticate a sense of belonging that was conceived and nurtured at a distance, back in Australia. Not all of the authors experience feelings of incongruence in Australia, and working-class origins offer immunity to some from the dream of belonging in France (see Chapter 6). Nonetheless, this pattern is prominent among the memoirs, and culminates in an idealised notion of 'being French', particularly among those whose 'French life' is short-term or part-time.

But when we consider the memoirs of those whose experience of France is full-time or long-term, a more complex pattern emerges. Unlike the successful appropriation of space performed by Savage et al.'s British interviewees, whose move to Manchester was intracultural and who "feel "at home" even when they have little or no contact with other local residents, and little or no history of residence in the area' $(2005,104)$, the feeling of belonging is not the end of the story in the Australian-in-France memoirs. The initial feelings of belonging experienced on arrival do not increase with length of stay and cultural immersion. On the contrary, they tend to dissipate, except among those who only live intermittently in France. ${ }^{8}$

Bourdieu explains that habitus is not simply an individual accomplishment:

to speak of habitus is to assert that the individual, and even the personal, the subjective, is social, collective. Habitus is a socialized subjectivity. (Bourdieu and Wacquant 1992, 126)

8 It is interesting to note that living only several months a year in France enables authors to avoid the unravelling of belonging. For Vicki Archer in My French Life, Jane Webster in French Ties and Susan Cutsforth in Our House is Not in Paris, it appears easier to call France 'home' when one has homes in different hemispheres and divides one's time between them. 
Even if one feels that one's habitus is incongruent with Australian suburbia, and better accommodated in France, habitus needs to be demonstrated through behaviour during social interaction. Here we see the role of the local audience marking the limits of the performance of belonging, and simultaneously marking the limits of the possibilities for elective belonging, which may well be easier to sustain in an intracultural move, as in the Manchester case study. For although elective belonging 'does not require people to get involved in the local community' (103), intercultural contact is inevitable during a prolonged stay, and unsettles the anticipated fit between sense of self and place of residence.

\section{Unravelling of belonging}

In the memoirs, sustained interaction with the local French population leads to much more tentative expressions of belonging, and we find clear moments of realisation by the authors that they are not French. This is particularly the case for the women with French partners, for whom the immersion experience of living with a Frenchman provides an antidote to feeling French. Although Marisa Raoul, Sarah Turnbull and Nadine Williams may start out with a desire to become more French, each comes to resist Frenchness. Although their integration is facilitated by the presence of a French partner, although they are gradually accepted into a French family, they each end up highlighting their Australianness. ${ }^{9}$ Australianness is not perceived in precisely the same way by these three women of different ages and backgrounds, but in each case serves as a pole of identification and of unbelonging-in-France.

Raoul's memoir is the least self-reflective on this point, but her identity strategy is thrown into relief when we compare her bed and breakfast establishment in Ma Folie Française with Vicki Archer's Provençal home in My French Life and French Essence. Whereas Archer endeavours to recreate the essence of Frenchness in every detail of her farmhouse, 'immers[ing] herself and her home in French customs, culture and style' (publisher's description, French Essence) although actually living there for only part of the year, Raoul's home 'became renowned for its antipodean hospitality [...] and eclectic décor' (2008, 32). Rather than French accessories,

9 Interestingly, the effect among the male authors with French wives, John Baxter and Stephen Downes, is much less marked. 
she chooses 'Spanish terracotta pots to adorn my front steps' (33) and 'create[s] name plates for each room, using exotic destinations as my theme and decorating them accordingly. They were "Isle of Skye", "Whitsunday" and "Koh Samui"' (43). She delights in discovering that 'the French [...] enjoyed the charm of my basic but enthusiastically spoken French' (32) and find her Australian accent sexy. In other words, she discovers and capitalises on her own exoticism as an Australian in France, and adopts the identity of the charming foreigner rather than striving to 'be French'.

While Marisa Raoul simply presents this position as a natural and profitable consequence of her situation, Sarah Turnbull and Nadine Williams recount their negotiation of an appropriate identity for themselves in France as a painful struggle, in which they need to assert their Australianness as a counterweight to a Frenchness that threatens to engulf them.

At first Turnbull imagines that belonging in France will take a matter of months (2002, viii), but it is not until 18 months later, when she and her French partner Frédéric move to the centre of Paris, that she feels 'the first stirrings of a sense of belonging' (110). She nonetheless still feels 'a newcomer-a foreign one at that' and wonders 'How long will it be [...] before I really feel part of it?' (124). As she grapples with French bourgeois culture, however, and gradually realises that the rules are different for every aspect of social relations, she comes to revise her expectations:

In the struggle to find my place in France I've discovered a million details that matter to me-details which define me as nonFrench. Much as I'd initially wanted to fully integrate, I knew now I never would, not completely, I couldn't, I didn't want to. This wasn't a choice, it simply wasn't possible. I will never be French. (156, original emphases)

The intimate knowledge of French culture that comes from sharing her daily life with a Frenchman persuades her that there are aspects of Frenchness that will remain forever alien to her. She realises that belonging fully is not only impossible, but also entails sacrifices that she is not prepared to make.

Nadine Williams recounts a five-week holiday of unrelenting cultural immersion in the homes of her partner's family and friends, where interminable meals, linguistic isolation and cramped suburban flats 
provide an authentic experience of French life in sharp contrast to the constant glamour and picturesqueness of the myth of France relayed in many of the memoirs. As a Francophile $(2007,20)$ with dreams of retiring to France (228), Williams is initially enticed by the fantasy of Frenchness. Her first morning in Paris produces her strongest feelings of belonging, when she is sent to buy bread and is elated at her success in speaking, looking and feeling French:

This is my first chance to try out my French on my own and I line up nervously, listening intently as each customer gives their order. When my time comes, I say as bravely and as confidently as I can, 'Une baguette traditionelle, sil vous plait.' I bid farewell to the shopkeeper with the same 'merci beaucoup' I've heard the other customers use. And now I look truly Parisian as I walk smugly along with my long baguette in its white paper wrapping. I wish I could skip back to breakfast. (52)

Soon, however, she feels the need to draw the line rather than blend in: 'I cannot bring myself to join in [a flirtatious exchange]. It's not me and it's not a part of my culture. I can't suddenly become French' (298). And as loss of identity increasingly becomes a distinct and visceral threat, she reaffirms a resolutely Australian identity: 'the one huge lesson of this trip has been how very precious my Australianness is' (229);

even though French culture has added such richness to my life, I'm still the same Australian Nadine and I always will be. I think like an Australian, I sound Australian, I live an Australian lifestyle and I have an absolutely Australian way of approaching the world. $(324)^{10}$

Of all the authors, Williams ends up most vehemently rejecting the possibility of belonging in France. The intensive nature of her immersion in French family life persuades her that a full-time French identity is not only unattainable for her, but not even desirable if it means giving up her Australianness.

If the presence of a French partner accentuates the Australianness of the author, having French children, in contrast, gradually increases a sense of belonging in France, although without increasing the sense of one's own Frenchness. Jane Paech, Henrietta Taylor and John Baxter have children who grow up in France and become acculturated. Baxter is the most

10 Cf. Pesman on travellers 'forging a stronger Australian identity while abroad' $(1996,173)$. 
explicit on this point, concluding his 2005 memoir as follows: 'Watching Louise grow has been like watching my own roots penetrating the French soil in a way they never quite managed to do in the hard-baked earth of Australia' (Baxter 2005, 347). This is a kind of vicarious belonging, belonging through another. Perhaps it is because one doesn't need to establish a counter-identity to one's children (that's the task of the younger generation!) in the way one does to one's partner, that the connection to French culture is stronger through having French children than through a French spouse. Both Taylor and Paech feel pride at the way their children gradually assimilate and absorb French norms and values (Paech 2011, 220; Taylor 2008, 28-32, 222). Initially sceptical of French educational practices, they come to value them (Paech 2011, 299-301; Taylor $2008,222)$ as they see their children learn and thrive. And it is worth noting that it is in response to daughter Annabelle speaking Frenchseveral years into their stay-that Paech first expresses a feeling of belonging: 'As Annabelle shyly asks for "Une baguette, SVP," I feel a sense of belonging - a part of the ebb and flow of Parisian life' (2011, 215). In contrast with those authors who feel immediately at home and claim Frenchness after a short stay, Baxter, Paech and Taylor only start to feel belonging much later. Taylor steadfastly maintains her Australian identity and that of her family, continuing to dream of 'crashing surf, sunburn, spicy Asian food, mangoes and cherries and the cricket' $(2008,1-2)$ and feeling a regular need to escape France:

Even with our three-year plan, we needed a quick trip back to Sydney at Christmas time for a break from all things French. The French, after all, were just too French! We were three Australians who still called Australia home. $(2008,2)$

This is one of frequent trips to reconnect with the Antipodes, which Taylor sees as particularly important for her children: 'They needed to be able to mimic the flat Australian vowels, understand the culture and cope at school; after all, there was no need to become totally French' (2008, 144). Her second volume in particular recounts her ambivalence towards loosening ties with Australia. She insists that she 'did not want to put down long and deep roots in France' $(2008,145)$ and only after five years, on the final page, does she start 'thinking seriously about digging [her] feet deep into the Provençal soil' (2008, 323), echoing Baxter's sentiments. 
Of course it is not only those with French spouses and children in French schools who interact extensively with Francophones. Several of the authors avoid the expat community, make an effort to leave their comfort zone and actively seek out intercultural contact. Elaine Lewis who opens the Australian bookshop in Paris, Maureen Cashman who takes on the role of visiting writer in a small village in the south-west, and Tony Davis who awards himself a self-funded sabbatical in Paris to write 'the great Australian novel' are prime examples in the corpus. All three emphasise their Australianness, an identity brought into relief against the surrounding culture. Davis seeks out French speakers for regular linguistic exchanges, and comes to know them well enough to be invited to their homes for Christmas, but at all times maintains an ironic and reflective distance from French habits of thinking and being. Lewis spends six years in Paris promoting Australian literature to the French through her bookshop and related literary events. Her integration is rewarded when a French radio interviewer introduces her as 'the most Parisian of Australians living in Paris'. Although she feels 'chuffed at that', it does not make her feel French and in fact, when the interviewer can't understand why she is not prepared to speak for Indigenous Australians, she 'leave[s] the radio station feeling deflated and much more Australian than Parisian' (2006, 270). Moments of crisis-being hospitalised, a hold-up at the bookshop, a bureaucratic nightmare forcing closure of her business-similarly reinforce her identity as 'an outsider, an alien' (230, cf. 223, 277).

Striking in these few memoirs is the awareness of the countless and often subtle differences that distinguish the authors from the French. Cashman, who earlier 'had begun cautiously to feel at home' $(2008,78)$ becomes acutely aware of the impossibility of being more than a well-adjusted migrant to the village, despite her integration into the local community, which has included writing a local history after many interviews with older inhabitants:

I realised that Espagnac couldn't really be my home, as it was for the [...] natives of the village. They were Espagnacois, Lotois; the countryside, their family stories, the houses they lived in, the local, regional and national politics and history belonged indisputably to them, were their identity. $M y$ identity, even while I was living in France, was still rooted in my relationships with friends and family in Australia and a very different cultural history and landscape. The same applied more or less to other migrants to the village 
[...], who spent the winters elsewhere, and whose other lives were just as complex and just as irrelevant to the real Espagnacois, as mine was. (271)

Her identity in the region can only ever be peripheral. On deciding to return, she reflects further on these differences:

I thought about the aspects of the lives of the Espagnacois that I knew very little about, and the kinds of skills and attitudes required for several generations and in-laws-indeed, for an entire village - to live in close proximity and apparent harmony. If I had chosen to stay, would I, in a changed role in the village, have wanted or been able to learn and develop those skills and attitudes? (313)

Belonging, for Cashman, requires changes to behaviour and mindset that, even were they possible, she may not be prepared to make. Cashman echoes Turnbull's discovery of the 'million details [...] which define me as non-French' $(2002,156)$. Like Cashman, Turnbull recognises the role of shared history in belonging:

After six years in France I feel like an insider. Having a French partner is a huge help, of course. But at the same time I'm still an outsider. And not just because of my accent or Anglo-Saxon appearance. To be a true insider you need that historical superglue spun from things like French childhood friends and memories of school holidays on the grandparents' farm and centuries of accumulated culture and complications. $(2002,298)$

While many authors write of being 'torn' being two cultures, only those with extensive contact with French locals are able to detail what precisely it would take to belong, and the sacrifices they would need to make. Despite feeling somewhat 'at home' in France (Cashman 2008, 223; Lewis 2006, 226, 230), they do not identify as French and highlight points of not belonging.

Similarly, the longer Bryce Corbett stays in France, the more he finds the need to surround himself with Australiana: 'In a city that had made it quite clear I was forever to be "un étranger", I had responded by asserting my essential Australianness' (2007, 178-79). Increasingly, he defines himself in contradistinction to the culture around him: 
I watched with alarm as the longer I was exposed to the liberté, egalité [sic], fraternité manifesto which is the ideological underpinning of the French republic, the more I began to resemble Attila the Hun. [...] I began to feel my long-harboured left leanings shifting inexorably towards the right. And it scared me. (209)

Paradoxically the greater the apparent opportunity to claim belonging through length of residence, immersion into French culture and interaction with local Francophones, the less inclined the authors are to do so. Indeed, those who sojourn the longest deliver very modest claims to belonging. Shay Stafford, after 12 years in Paris dancing at the Moulin Rouge and the Lido, sees herself as: 'No longer completely Australian, no hope of ever being completely French' (Stafford 2010, 367). Baxter, after 18 years in Paris, is grateful 'Not to be cast out, no longer to be [...] a stranger' $(2008,270)$. Far from flaunting Frenchness, far from seeing integration as his due, Baxter is content not to be excluded.

In these memoirs of in-depth intercultural contact, we see that rather than confirming a projected identity, relocation to France risks bringing about a sense of affective dislocation: the pragmatic realities of intercultural contact ultimately hamper attempts to perform one's identity in such a way that it would enact a sense of belonging. Floya Anthias, in 'Belongings in a Globalising and Unequal World', points to the necessity of 'meeting the criteria of inclusion' (2006, 22): 'to belong is to be accepted as part of a community, [...] to share values, networks and practices and it is not just a question of identification' (21). Electing one's place of belonging can only take one so far, for whilst from afar we may identify a fit between sense of self and place of potential residence, on site it needs to be negotiated with others.

\section{Belonging in motion}

The strands of belonging thus far discussed-embodied routines and practices, elective belonging, performance and the spectre of its failureare brought together in a helpful way by Elspeth Probyn, whose conception of belonging in Outside Belongings (1996) comes closest to explaining the trajectory of the authors. Probyn identifies 'the longing in belonging' (13), when she writes of 'other manners of being and desires for becomingother that I call belonging' (5), and elaborates her understanding as: 
the desire for some sort of attachment, be it to other people, places, or modes of being, and the ways in which individuals and groups are caught within wanting to belong, wanting to become, a process that is fuelled by yearning rather than the positing of identity as a stable state. (19)

Wishing however is only part of the process; individuals 'know [... full well that belonging is not an individual action, that it is always conducted within limits' (24), limits traced by others. Rather than being located, Probyn theorises belonging as 'inbetweenness' (19), as 'the movement that the wish to belong carries' (7), as a precarious form of momentum, 'like the moment when the trapeze artist has let go of one ring but hasn't yet grasped the other' (42), as something inherently unstable.

This conception is furthest from the idea of belonging as rootedness, as being comfortably culturally embedded. Rather than a feeling of presence and oneness, a certain distance is inscribed in its very possibility. Unlike a sediment or a groove of practice, belonging in Probyn's view is a projection of a self-in-motion, reaching out towards an uncertain cultural hold. It is not a unidirectional pathway from outsider to insider status, but something more complex, fragile and fluid.

This perspective can be used to explain the pattern in the memoirs whereby belonging starts to unravel once travel is accomplished and dwelling begins. Ultimately, what the memoirs (and the tour of theory they have occasioned) enable us to understand is that the fullest expressions of belonging are shimmering, transitory, elusive, nourished by distance. For the authors, France at first provides an elsewhere into which a certain sense of oneself can be projected, often in contradistinction to other Australians. On arrival in France, the sense of belonging rehearsed and nurtured in Australia is initially embodied by bedding down local routines. We could say that it is approximated, in the sense that made proximate for distant readers through performance in situ. Gradually, however, the authors find that these spatial practices are not sufficient to sustain belonging. Interaction with the local French, beyond service encounters with shopkeepers, reveals a lack of shared codes of understanding and dents illusions of homecoming. Those who engage in depth with the local French-speaking population on a daily basis are surprised to find their Australianness becoming more and more salient, confirmed via the displacement to France. And yet, we can anticipate that these feelings of Australian belonging are similarly dependent on and protected by 
distance to a large extent, in this case the distance from the Antipodes, and that they too are liable to abate in proximity to Australian suburbia. Meanwhile, the immersive encounter with French culture leads longerterm residents to trace an idiosyncratic path, oscillating-like Probyn's trapeze artist-between identifications as they negotiate opportunities and setbacks, resulting in moments of congruence between self and place, rather than a secure sense of being at home in France.

\section{What's being there got to do with it?}

The cornerstone of the marketing of the memoirs is the author's status as an insider in France, able to provide insights beyond those available to the casual tourist and to share a sense of belonging. Being there is thus an obvious prerequisite for publication. It plays a paradoxical role, however, in the telling of the insider story. Although being in France lends authority to the insider's view to which the books lay claim, prolonging the stay doesn't simply confirm feelings of belonging, but often leads to feelings that are much more mitigated, complex and fluid.

Being there, living in France, can be understood in many cases as the end result of processes of identification that led the authors to pin their sense of self on another country. In other words, what prompts the memoirs is not so much 'being there' as the work of belonging that was carried out back home, prior to travel. Just as critical as being there is the investment in France, the identification with a country on the other side of the globe.

Certainly the mobility we see among the authors, allowing them to uproot and transplant themselves on the other side of the world, is characteristic of a postmodern, globalised world, in which 'culturally unsettled individuals $[\ldots]$ are expressing their search for identity in spatial terms' (Jones 2007, 60). But if claims about feeling at home are 'a manifestation of an investment of meaning in space' (Silverstone 1994, 28), what then are the particular meanings attached by Australians-and above all Australian women-to being in France? What persuades the authors to invest fantasmatically in France, to project themselves and their dreams into a distant place? What are they seeking that is apparently unavailable in Australia? The covers of the memoirs suggest that love and romance play a significant role. Let us look, then, at the love angle, and ask 'What's love got to do with it?' 
This text is taken from What's France got to do with it?: Contemporary memoirs of Australians in France, by Juliana de Nooy, published 2020 by ANU Press, The Australian National University, Canberra, Australia.

doi.org/10.22459/WF.2020.03 